\title{
Thyroid Control over Biomembranes
}

\author{
Rat Liver Mitochondrial Inner Membranes ${ }^{1}$
}

\author{
Y.-D. IDA CHEN AND FREDERIC L. HOCH
}

\begin{abstract}
Departments of Biological Chemistry and Internal Medicine, University of Michigan Medical School, Ann Arbor, Michigan 48109
\end{abstract}

Received January 17, 1977

\begin{abstract}
The effects of hypothyroidism and one injection of L-thyroxine on oxidative phosphorylation and the composition of proteins and phospholipids were examined in vesicles prepared from rat liver mitochondria by digitonin extractions. At $30^{\circ} \mathrm{C}$, the rates of $\mathrm{ADP}$ phosphorylation in sites I and II were below normal, and $\mathrm{Mg}^{2+}$-ATPase activity was greater than normal in vesicles from hypothyroid rats. At temperatures below $20^{\circ} \mathrm{C}$ and above $30^{\circ} \mathrm{C}$, the $\mathrm{Mg}^{2+}$-ATPase was not accelerated above normal rates, a feature of temperature dependence shared by ADP phosphorylation (Chen, Y.-D. I., and Hoch, F. L., 1976, Arch. Biochem. Biophys. 172, 741-744). Respiration at $30^{\circ} \mathrm{C}$ was undiminished in hypothyroid vesicles, as were the flavin and cytochrome contents, and thyroxine administration corrected the phosphorylation rate at $30^{\circ} \mathrm{C}$ in 3 days without changing either respiration or electron-carrier contents. The $30^{\circ} \mathrm{C}$ phosphorylation defect comprised a decreased $V$ and $K_{m}$ for ADP and a decrease in the number of phosphorylating sites (measured with oligomycin) that accounted for most of the decreased phosphorylation rates, either dependent on or independent of the adenine nucleotide carrier. Vesicles from hypothyroid rats were not detectably depleted in major protein subunits, but were abnormal in phospholipid fatty acid contents. Thyroxine injection corrected the low unsaturation index of the fatty acids and the membrane contents of linoleic acid and its fatty acyl metabolites. Hypothyroidism appears to affect oxidative phosphorylation through the altered inner membrane lipid environment, which implies that previously reported direct, reversible effects of thyroxine may mimic repletion of the membranes with unsaturated fatty acyl groups.
\end{abstract}

The relationship between oxidative phosphorylation and the thyroid state of rats has previously been examined in intact rat liver mitochondria. In hypothyroidism, the rates of State 3 oxidation of many substrates and the coupled phosphorylation of added ADP are equally decreased as compared with mitochondria

\footnotetext{
${ }^{1}$ Paper I of this series is Ref. 8; Paper II is Ref. 60. This work was supported in part by grants from the National Institutes of Health (No. AM13654-03), The John A. Hartford Foundation, and the National Science Foundation (No. GR42256). The data were taken from a dissertation submitted by Y.-D. I. Chen to the University of Michigan in partial fulfillment of the requirements for the degree of Doctor of Philosophy. Y.-D. I. Chen was supported in part by a National Institutes of Health grant (No. 5-SO1RR05373-13).
}

from normal rats $(1,2)$. Respiratory control is increased in hypothyroidism through an even greater decrease in State 4 respiration $(2,3)$. The atractyloside-sensitive ADP carrier in the inner membrane may not limit oxidative phosphorylation in hypothyroids at temperatures above about $25^{\circ} \mathrm{C}(4,5)$. Inner membrane vesicles prepared by digitonin extractions of the liver mitochondria of hypothyroid rats-hereafter referred to as hypothyroid vesicles phosphorylate ADP more slowly at $30^{\circ} \mathrm{C}$ than do vesicles from normal rats, but respire at a normal rate. The depressed phosphorylation is connected with an abnormal response of velocity to temperature changes and with a redistribution of membrane polyunsaturated fatty acid contents; both abnormalities are corrected 3 days 
after one injection of $\mathrm{L}$-thyroxine (6-8). Oxidative phosphorylation and inner membrane composition are further examined in this report.

\section{MATERIALS AND METHODS}

Four different groups of male rats were used, as follows. (a) Normal Sprague-Dawley rats weighing 175-200 g were obtained from Spartan Animal Research, Haslett, Michigan, and maintained on Rockland rat/mouse chow and tap water. (b) Three-weekold thyroidectomized rats of the same strain were injected intraperitoneally with $0.5 \mathrm{mCi}$ of ${ }^{131} \mathrm{I}$ (as iodide) per rat and kept 3 to 4 weeks before use. They were maintained on $1 \%$ calcium lactate solution and on a low-iodine test diet (Nutritional Biochemicals Corp., Cleveland) to keep them hypothyroid, because ordinary lab chows contain thyroid-active materials (9). (c) Hypothyroid rats were injected intraperitoneally with $0.5 \mu \mathrm{g}$ of L-thyroxine/g of body weight and then. sacrificed on the fourth day after injection. The thyroxine was prepared at $0.5 \mathrm{mg} / \mathrm{ml}$ in $0.0005 \mathrm{~N} \mathrm{NaOH}$. Control rats were injected at the same time with the $\mathrm{NaOH}$ solution only. (d) Normal rats were kept on the low-iodine diet for at least 1 month before use, and a $0.0005 \% \mathrm{KI}$ solution was substituted for their water to provide them with iodine. Rats on this diet grew in length and weight normally and were used as the control group for lipid analyses of mitochondrial inner membrane vesicles.

Inner membrane vesicles were prepared at $0^{\circ} \mathrm{C}$ (10). Rat livers were homogenized in a glass homogenizer, using about $4 \mathrm{~g}$ of wet tissue in $20 \mathrm{ml}$ of 0.25 M sucrose-1 mM EDTA (pH 7.4), and centrifuged at $700 \mathrm{~g}$ for $10 \mathrm{~min}$. The dense pellet was washed and recentrifuged. The combined supernatant was spun at $7000 \mathrm{~g}$ for $10 \mathrm{~min}$. The resulting mitochondrial pellet was washed once with sucrose-EDTA and resuspended in sucrose-EDTA to give a concentration of 70 to $100 \mathrm{mg}$ of protein $/ \mathrm{ml}$. Enough $10 \%$ digitonin was then added to give a final ratio of $0.11 \mathrm{mg}$ of digitonin $/ \mathrm{mg}$ of protein. The mixture was incubated for $20 \mathrm{~min}$ at $0^{\circ} \mathrm{C}$ with occasional mixing and then diluted with 3 vol of sucrose-EDTA and centrifuged at $45,000 \mathrm{~g}$ for $20 \mathrm{~min}$. The pellet was washed with sucrose-EDTA and resuspended in enough $0.5 \%$ aqueous digitonin to give $1.5 \mathrm{mg}$ of digitonin $/ \mathrm{mg}$ of protein in the pellet; the amount of protein in the second mitochondrial pellet was found to be about half of that in the first mitochondrial pellet. The resulting suspension was immediately centrifuged at $105,000 \mathrm{~g}$ for $30 \mathrm{~min}$, and the pellet was resuspended in a $3 / 4$ vol of $0.5 \%$ digitonin and spun again for $30 \mathrm{~min}$. The final pellet was washed once and suspended in sucrose-EDTA at 7 to $10 \mathrm{mg}$ of protein/ $\mathrm{ml}$.

Total protein was estimated by a biuret method
(11) with $0.16 \%$ deoxycholate added to dissolve membrane proteins; bovine serum album in was used as a reference.

ATP synthesis was measured according to Conover et al. (12), in a $0.5-\mathrm{ml}$ assay mixture at $\mathrm{pH} 7.2$ containing 5 mм ADP; $5 \mathrm{~mm} \mathrm{MgSO}_{4} ; 25 \mathrm{~mm}$ glucose, $20 \mathrm{~mm}$ Tris sulfate, $10 \mathrm{mM} \mathrm{P}_{\mathrm{i}} ; 5$ units of hexokinase; $10^{6} \mathrm{cpm}$ of ${ }^{32} \mathrm{P}_{1} ; 20 \mathrm{~mm} \beta$-hydroxybutyrate plus 1.0 $\mathrm{mm} \mathrm{NAD}{ }^{+}, 10 \mathrm{~mm}$ succinate, or $2.5 \mathrm{~mm} \mathrm{NADH}$ as substrate; $0.05 \mathrm{ml}$ of a vesicle suspension to start the reaction; and $0.05 \mathrm{ml}$ of $35 \%$ perchloric acid to stop the reaction. The reaction was linear for $5 \mathrm{~min}$ at $30^{\circ} \mathrm{C}$. Organic phosphate was extracted according to Conover et al. (12), and 2-ml aliquots were added to 8 $\mathrm{ml}$ of Tris- $\mathrm{HCl}, \mathrm{pH} \mathrm{7.4}$, and $2 \mathrm{ml}$ of $1 \mathrm{~N} \mathrm{KOH}$ in a scintillation vial. Cerenkov radiation was measured in a Packard liquid scintillation counter. No corrections for quenching were found to be necessary.

ATP- $P_{1}$ exchange (12) was determined in a reaction mixture similar to that for ATP synthesis except that $10 \mathrm{~mm}$ ATP was substituted for the ADP, and substrates, hexokinase, and glucose were omitted. The exchange at $30^{\circ} \mathrm{C}$ was linear for about 20 min with intact mitochondria and 5 min with vesicles.

ATPase activity (13) was measured in a mixture at pH 7.2 containing $10 \mathrm{~mm}$ ATP, $5 \mathrm{~mm} \mathrm{MgSO}_{4}, 20$ $\mathrm{mM}$ Tris sulfate, and about $0.5 \mathrm{mg}$ of vesicle protein; the volume was $0.50 \mathrm{ml}$. Temperatures were held constant, between 8 and $35^{\circ} \mathrm{C}$. The reactions were run for 2 to $10 \mathrm{~min}$, stopped by addition of $0.05 \mathrm{ml}$ of $35 \%$ perchloric acid, and centrifuged. The supernatant was analyzed for $P_{i}$ (14).

Oxygen uptake by inner membrane vesicles was measured in a 1-ml glass chamber at $30^{\circ} \mathrm{C}$ using a Clark oxygen electrode (Yellow Springs Instrument Company) and a Gilson oxygraph. The concentrations of reactants were the same as in the ATP synthesis experiments, but hexokinase was omitted (with no resultant change in respiration).

Cytochrome difference spectra of oxidized and succinate-reduced inner membrane vesicles were recorded on a split-beam Aminco-Chance spectrophotometer. The extinction coefficients determined by Chance (15) were used to calculate the concentrations of the cytochromes and flavoproteins.

Polyacrylamide gel electrophoresis was performed according to Weber and Osborn (16). The inner membrane vesicle suspension was heated with sodium dodecyl sulfate at $70^{\circ} \mathrm{C}$ for $2 \mathrm{~min}$ and then made up to final concentrations of about $6 \mathrm{ml}$ of protein $/ \mathrm{ml}$ in $2.5 \%$ sodium dodecyl sulfate, $60 \mathrm{~mm}$ Tris- $\mathrm{HCl}, \mathrm{pH} 8.8$, and $10 \mathrm{~mm}$ dithiothreitol. Aliquots of $50-100 \mu \mathrm{l}$ were electrophoresed at $2 \mathrm{~mA}$ for $30 \mathrm{~min}$ and than at $5 \mathrm{~mA}$ for about $2 \mathrm{~h}$, fixed, stained with Coomassie blue, thoroughly washed, and then scanned with a Gilford Model 2000 spectrophotometer equipped with a Gilford Model 2410 linear transport gel scanner. 
Lipids were extracted from freshly prepared suspensions of inner membrane vesicles containing 10 to $20 \mathrm{mg}$ of protein by the method of Folch et al. (17). Aliquots of extracts were weighed. Aliquots of extracts, plus an internal standard fatty acid, 23:0 or 24:0, were methanolyzed according to Morin et al. (18). The fatty acid methyl esters were dissolved in hexane. Cholesterol and hydrocarbons were removed on a Unisil silica gel column. Gas-liquid chromatography of the fatty acid methyl esters was carried out (through the courtesy of Dr. N. Radin) on a Barber-Coleman gas chromatograph equipped with a hydrogen flame ionization detector maintained at $250^{\circ} \mathrm{C}$. The column was packed with $100 /$ 200 mesh, Gas Chrom Q with Silar 10-C as the stationary phase, $10 \mathrm{~g}$ Gas Chrom Q/g Silar 10-C. Fatty acids present in amounts less than $0.1 \%$ of the most abundant fatty acid were ignored.

\section{RESULTS}

Oxidative phosphorylation. We have previously reported that at $30^{\circ} \mathrm{C}$ hypothyroid vesicles phosphorylate added ADP more slowly than normal vesicles do, but they concomitantly oxidize $\beta$-hydroxybutyrate $+\mathrm{NAD}^{+}$at an undiminished rate (6-8). These data are repeated in Table I to allow comparison with the rates observed with NADH or succinate as substrate. Hypothyroid vesicles phosphorylate ADP at a rate of about $45 \%$ less than do normal vesicles when NADH, succinate, or $\beta$-hydroxybutyrate is oxidized. A 3-day interval after injecting hypothyroid rats with hor- mone restores the phosphorylation rates to normal levels. The hypothyroid vesicles oxidize each of the three substrates at rates not significantly different from those seen with normal vesicles. Pre-injection of hypothyroid rats with hormone does not change the rates of oxidation. 'These data thus demonstrate that the efficiency of phosphorylation, in terms of $\mathrm{P}: \mathrm{O}$ ratios measured at $30^{\circ} \mathrm{C}$, is decreased 60 to $70 \%$ in hypothyroidism and is corrected in 3 days after hormone administration.

Both phosphorylation and State 3 respiration are equally slowed in intact mitochondria from the livers of hypothyroid rats $(1,2)$. Phosphorylation is selectively slowed in vesicles prepared by digitonin extractions of hypothyroid mitochondria (Table I). Phosphorylation in vesicles prepared from either hypothyroid or normal rats is inhibited 95 to $100 \%$ by the addition of $12.8 \mu \mathrm{g}$ of oligomycin $/ \mathrm{mg}$ of protein, 0.2 mM 2,4-dinitrophenol or $3.2 \mu \mathrm{M}$ carbonyl cyanide $m$-chlorophenylhydrazone, or by the omission of ADP or $\mathrm{P}_{\mathrm{i}}$. Respiration is not changed by such additions or omissions. Thus, all phosphorylation is specific for mitochondrial respiration, and these phosphorylating vesicles are loosely coupled. In loosely coupled submitochondrial particles, with the rate of respiration being independent of that of phosphorylation, the defects in the phosphorylation

TABLE I

Oxidative Phosphorylation at $30^{\circ} \mathrm{C}$ in Mitochondrial Inner Membrane Vesicles Prepared from the Livers of Normal, Hypothyroid, or Thyroxine-InJected Hypothyroid RAts ${ }^{a}$

\begin{tabular}{|c|c|c|c|c|c|c|}
\hline \multirow[t]{2}{*}{ Substrate } & \multicolumn{2}{|c|}{ Normals } & \multicolumn{2}{|c|}{ Hypothyroids } & \multicolumn{2}{|c|}{$\begin{array}{l}\text { Hypothyroids }+ \text { L-thyrox- } \\
\text { ine }\end{array}$} \\
\hline & $\begin{array}{c}\text { Phosphoryla- } \\
\text { tion rate }\end{array}$ & $\begin{array}{l}\text { Oxygen up- } \\
\text { take rate }\end{array}$ & $\begin{array}{l}\text { Phosphoryla- } \\
\text { tion rate }\end{array}$ & $\begin{array}{l}\text { Oxygen up- } \\
\text { take rate }^{c}\end{array}$ & $\begin{array}{l}\text { Phosphoryla- } \\
\text { tion rate }\end{array}$ & $\begin{array}{l}\text { Oxygen up- } \\
\text { take rate }\end{array}$ \\
\hline $\begin{array}{l}20 \mathrm{~mm} \beta \text {-hydroxy- } \\
\text { butyrate }+1 \\
\text { mM NAD }^{+}\end{array}$ & $145^{d} \pm 5.3(13)$ & $101 \pm 10(9)$ & $76.9 \pm 7.6(6)$ & $131 \pm 29(4)$ & $158^{d} \pm 7.8(5)$ & $131 \pm 24(4)$ \\
\hline $2.5 \mathrm{~mm} \mathrm{NADH}$ & $88.0^{d} \pm 2.0(3)$ & $63 \pm 3(3)$ & $48.8 \pm 4.5(5)$ & $122 \pm 21(4)$ & $80.3^{d} \pm 0.9(5)$ & $106 \pm 19(4)$ \\
\hline $10 \mathrm{~mm}$ succinate & $52.1^{e} \pm 2.1(5)$ & $86 \pm 14(4)$ & $29.4 \pm 5.9(5)$ & $114 \pm 32(4)$ & $47.9^{e} \pm 2.6(5)$ & $107 \pm 21(4)$ \\
\hline
\end{tabular}

a The maintenance and pretreatment of the animals, the preparation of vesicles, and the measurements of ATP synthesis and $\mathrm{O}_{2}$ consumption are described under Materials and Methods. The results are shown as means \pm SEM, with the number of experiments in parentheses.

${ }^{b}$ Nanomoles of ATP $\times$ minutes $^{-1} \times$ (milligrams of protein $)^{-1}$.

c Nanogram atoms of oxygen $\times$ minutes $^{-1} \times$ (milligrams of protein $)^{-1}$.

${ }^{d, e} P<0.001$ (d) or 0.025 (e) for normals or hypothyroids + L-thyroxine versus hypothyroids, calculated by Student's $t$ test for unequal groups of experiments, where appropriate. For all other differences between means, $P>0.05$. 
rate and $\mathrm{P} / \mathrm{O}$ ratio at $30^{\circ} \mathrm{C}$ are detectable in hypothyroidism; in contrast, in intact hypothyroid mitochondria, the slow rate of phosphorylation appears to decrease the tightly coupled State 3 respiration and no inefficiency is apparent. These observations imply that a defect in phosphorylation causes the decreased respiration in intact mitochondria from hypothyroid rats, and not vice versa.

Neither hypothyroidism nor the injection of hypothyroid rats with thyroxine changes the ratio of the flavins or the cytochromes to total vesicle protein (Table II). This constancy is consistent with the lack of contribution of respiratory rates to the low phosphorylation rates.

Partial reactions of oxidative phosphorylation were examined in attempts to localize the apparent defect in phosphorylation of ADP. In either intact live mitochondria or vesicles, the exchange of the $\gamma$ phosphate of ATP with $\mathrm{P}_{\mathrm{i}}$ at $30^{\circ} \mathrm{C}$ was inhibited 95 to $98 \%$ in the presence of $1.8 \mu \mathrm{g}$ of oligomycin $/ \mathrm{mg}$ of protein or of $0.2 \mathrm{mM}$ dinitrophenol, showing that this partial reaction was specific for oxidative phosphorylation. The inhibitions were similar when the particles were prepared from hypothyroid or normal rats. In intact mitochondria from hypothyroid rats, the uninhibited exchange rate is $34 \%$ less than in

\section{TABLE II}

Electron Carriers of InNer Membrane Vesicles Prepared from the Livers of Normal, HYPOTHYROID, OR THYROXINE-INJECTED HYPOTHYROID RATs ${ }^{a}$

\begin{tabular}{lccc}
\hline $\begin{array}{c}\text { Electron car- } \\
\text { rier }\end{array}$ & $\begin{array}{c}\text { Normals } \\
(4)^{b}\end{array}$ & $\begin{array}{c}\text { Hypo- } \\
\text { thyroids } \\
(8)^{b}\end{array}$ & $\begin{array}{c}\text { Hypothy- } \\
\text { roid }+ \text { L- }^{-} \\
\text {thyroxine } \\
(4)^{b}\end{array}$ \\
\hline Flavoprotein & - & $813 \pm 27$ & $1000 \pm 185$ \\
Cytochrome $b$ & $165 \pm 4$ & $167 \pm 8$ & $173 \pm 46$ \\
$\begin{array}{c}\text { Cytochrome } c \\
+c_{1}\end{array}$ & $449 \pm 57$ & $381 \pm 42$ & $388 \pm 46$ \\
$\begin{array}{l}\text { Cytochrome } a_{3} \\
\text { Cytochrome } a\end{array}$ & $551 \pm 36$ & $540 \pm 34$ & $458 \pm 100$ \\
\hline
\end{tabular}

${ }^{a}$ Difference spectra of oxidized and succinatereduced vesicles were used to calculate electroncarrier contents, as described under Materials and Methods. 'The number of experiments is shown in parentheses, and the results are given as means \pm SEM.

${ }^{0}$ Picomoles $\times$ (milligrams of protein $)^{-1}$.
TABLE III

ATP-P ${ }_{i}$ Exchange Rates at $30^{\circ} \mathrm{C}$ in Intact Mitochondria and in Inner Membrane Vesicles OBTAINED FROM NORMAL AND HYPOThyroId RATS ${ }^{a}$

\begin{tabular}{lcc}
\hline & Normal $^{b}$ & Hypothyroid $^{b}$ \\
\hline $\begin{array}{l}\text { Intact mitochondria } \\
\quad 15)\end{array}$ & $100.0 \pm 5.9$ & $65.6^{c} \pm 2.7$ \\
$\begin{array}{l}\text { Inner membrane } \\
\text { vesicles (8) }\end{array}$ & $53.2 \pm 2.3$ & $48.5 \pm 3.3$ \\
& &
\end{tabular}

${ }^{a}$ Exchange rates were measured as described under Materials and Methods and are given as means \pm SEM, with the number of experiments shown in parentheses.

${ }^{b}$ Nanomoles of ATP per minute per milligram of protein.

${ }^{c} P<0.001$.

mitochondria from normal rats (Table III). Digitonin extractions of mitochondria from hypothyroid rats decrease the rate of exchange less (25\%) than in normals $(50 \%)$ and in this way produce vesicles with equivalent exchange rates.

The $\mathrm{Mg}^{2+}$-activated ATPase activity of inner membrane vesicles at $30^{\circ} \mathrm{C}$ was inhibited upon the addition of $10 \mu \mathrm{g}$ of oligomycin/mg of protein: $83 \%$ in normals and $89 \%$ in hypothyroids. In an experiment at $30^{\circ} \mathrm{C}$, the ATPase activity was $288 \pm 18$ (SE) $\mathrm{nmol}$ of $\mathrm{P}_{\mathrm{i}} / \mathrm{min} / \mathrm{mg}$ of protein for 11 preparations of normal vesicles, $462 \pm 48$ units for 13 hypothyroids $(P<0.005)$, and $326 \pm 52$ units $(P>0.1$ vs hypothyroids $)$ for 5 batches of vesicles prepared from thyroxine-injected hypothyroid rats. The effect of varying the temperature between 8 and $35^{\circ} \mathrm{C}$ upon $\mathrm{Mg}^{2+}$-ATPase activity is shown in Fig. 1. Hypothyroid vesicle activity is significantly greater than normal only at temperatures below 35 and above 20 to $22^{\circ} \mathrm{C}$; below $20^{\circ} \mathrm{C}$, the hypothyroids are consistently less active.

The nature of the apparent defect in phosphorylation at $30^{\circ} \mathrm{C}$ was further examined by measuring the dependence of the rate of ATP synthesis upon the concentration of added ADP (Fig. 2, the uninhibited reaction). Values of the apparent $K_{m}$ and $V$, shown in Table IV, are 35 and $58 \%$ lower, respectively, in vesicles from hypothyroid rats than in vesicles from normal rats. The change in $K_{m}$ suggests either that the affinity of hypothyroid vesicle 
phosphorylating sites for ADP is changed or, assuming that the mechanism of phosphorylation is similar in hypothyroid and normal vesicles, that a rate-limiting step is changed.

Phosphorylation of exogenous ADP by intact liver mitochondria is mediated by an atractyloside-sensitive translocator in the inner membrane, which also has a decreased $V$ and $K_{m}$ for ADP at temperatures

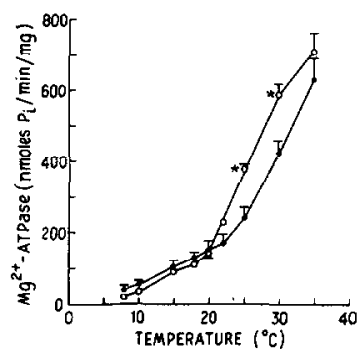

FIG. 1. $\mathrm{Mg}^{2+}$-activated ATPase activity as a function of temperature in inner membrane vesicles obtained from normal (O) or hypothyroid (O) rats. Reactant concentrations are described under Materials and Methods. The number of vesicle preparations was three to seven for normals and one to three for hypothyroids; means $+\mathrm{SE}$ are shown where appropriate, and the asterisks represent differences with $P<0.025$, calculated by Student's $t$ test for equal or unequal group numbers. below about $25^{\circ} \mathrm{C}$ in hypothyroidism $(4,5)$. The contribution of the specific translocator to the phosphorylation of added ADP by inner membrane vesicles at $30^{\circ} \mathrm{C}$ was examined by measuring the sensitivity of ATP synthesis (substrate, $\beta$-hydroxybutyrate) to atractyloside. Atractyloside in concentrations of up to $2 \mu \mathrm{M}$ inhibits ATP synthesis competitively with ADP in both normal and hypothyroid vesicles (Fig. 2). The values for the apparent $K_{i}$ (Table V) show that atractyloside inhibits the phos-

TABLE IV

The Kinetics of ATP Synthesis at $30^{\circ} \mathrm{C}$ with

Respect to ADP Concentration IN INNER

Membrane Vesicles from Normal aNd HYPOTHYROID RATS ${ }^{a}$

\begin{tabular}{lcc}
\hline & $\begin{array}{c}\text { Normal } \\
(4)\end{array}$ & $\begin{array}{c}\text { Hypothyroid } \\
(3)\end{array}$ \\
\hline$V$ (nmol of ATP/min/ & $178 \pm 9.1$ & $74.9^{b} \pm 8.4$ \\
mg of protein) & $39.7 \pm 3.4$ & $26.0^{c} \pm 2.1$
\end{tabular}

${ }^{a}$ The values of $V$ and $K_{m}$ were obtained from the plots of reciprocal uninhibited velocity versus $[\mathrm{ADP}]^{-1}$ in Fig. 2. The number of experiments is shown in parentheses, and values are given as means \pm SEM.

${ }^{b} P<0.001$.

${ }^{\mathrm{c}} P<0.025$.

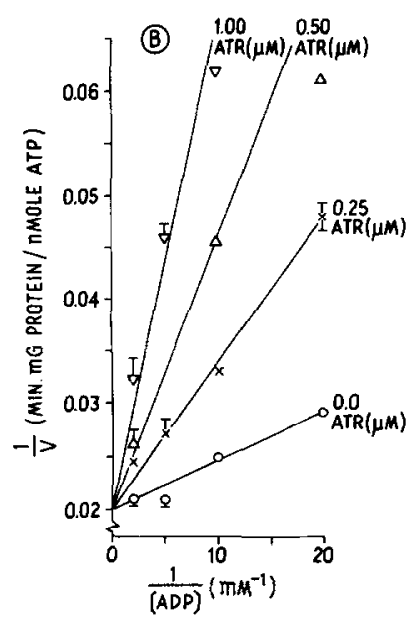

FIG. 2. Atractyloside (ATR) inhibition of ATP synthesis at $30^{\circ} \mathrm{C}$ when [ADP] is varied; Lineweaver-Burk plots. Inner membrane vesicles were obtained from the livers of normal (A) and hypothyroid (B) rats. The substrate was $20 \mathrm{~mm} \beta$-hydroxybutyrate plus $1 \mathrm{~mm} \mathrm{NAD}$, and other reactants were as shown in Table I and under Materials and Methods. The values for $V$ and $K_{m}$ of the uninhibited reaction are shown in Table IV, and the values for $K_{i}$ are shown in Table V. 
TABLE $\mathrm{V}$

Atractyloside InHIBItion of ATP SyNThesis BY InNer Membrane Vesicles from Normal aNd HYPOTHYROID RATs ${ }^{a}$

\begin{tabular}{lcc}
\hline & Normal & Hypothyroid \\
\hline$K_{i}(\mu \mathrm{M})$ & $0.39 \pm 0.07$ & $0.19^{b} \pm 0.03$
\end{tabular}

$V($ nmol of ATP $\times$

(4)

$\min ^{-1} x$ $\mathrm{mg}^{-1}$ )

Atractyloside insensitive

Atractyloside 68

sensitive

a The values for $K_{i}$ were obtained from Fig. 2 . The values for $V$ are calculated from the degree of inhibition of ATP synthesis in the presence of $50 \mu \mathrm{M}$ atractyloside and the uninhibited $V$ in Table IV. The atractyloside-sensitive $V$ is calculated by difference.

${ }^{b} P<0.05$.

phorylation of added ADP by hypothyroid vesicles twice as effectively as that by normal vesicles. The deviation from the competitive mode of inhibition at concentrations of atractyloside near $2 \mu \mathrm{M}$ seems to arise from residual phosphorylation activity that is not inhibited by $50 \mu \mathrm{M}$ atractyloside and therefore is presumably not mediated by the nucleotide carrier. The incompletely competitive nature of the inhibition (Fig. 2) leaves open the possibility that the apparent $K_{\mathrm{i}}$ is not a true affinity constant for atractyloside, since a partially competitive inhibition involves mutual equal influences of the inhibitor and the substrate upon affinities for the catalytic sites (19).

The overall 58\% decrease in phosphorylation $V$ in hypothyroid vesicles, as compared with normals (Table IV), comprises a $49 \%$ decrease in carrier-mediated phosphorylation and a $72 \%$ decrease in carrierindependent phosphorylation (Table V). The portion of the overall $V$ that represents direct phosphorylation of added ADP is only $25 \%(19 / 74.9)$ in hypothyroid vesicles and $38 \%(68 / 178)$ in normal vesicles. The eversion of a smaller number of phosphorylation sites (either because there are fewer sites or because digitonin extractions selectively evert fewer), or the eversion of sites that have a lower specific phosphorylation activity, in hypothyroid vesicles would account for the slower direct phosphorylation.

A specific high-affinity inhibitor of phosphorylation was therefore used to measure the total number of phosphorylation sites. The inhibition by oligomycin involves a depletion of free inhibitor through binding by phosphorylation sites and is formulable in terms of site concentrations, $E_{\mathrm{t}}(20,21)$ :

$$
I_{\mathrm{t}} /\left(1-v_{i} / v_{0}\right)=K_{i} v_{0} / v_{i}+E_{\mathrm{t}},
$$

where $v_{i}$ and $v_{0}$ are phosphorylation rates in the presence and absence of inhibitor, $I_{t}$ is total oligomycin concentration, and $K_{i}$ is the inhibitor binding constant. Plots of $I_{t} /\left(1-v_{i} / v_{0}\right)$ against $v_{0} / v_{i}$, comparing vesicles from normal and hypothyroid rats, are shown with $\beta$-hydroxybutyrate (Fig. 3A) and succinate (Fig. 3B) as substrates. The values for $K_{i}$ are similar in normal and hypothyroid vesicles, suggesting an equal affinity between oligomycin and the phosphorylating sites. $E_{\mathrm{t}}$ is lower in hypothyroid vesicles than in normals, by $36 \%$ with $\beta$-hydroxybutyrate as substrate and by $47 \%$ with succinate. Compar-

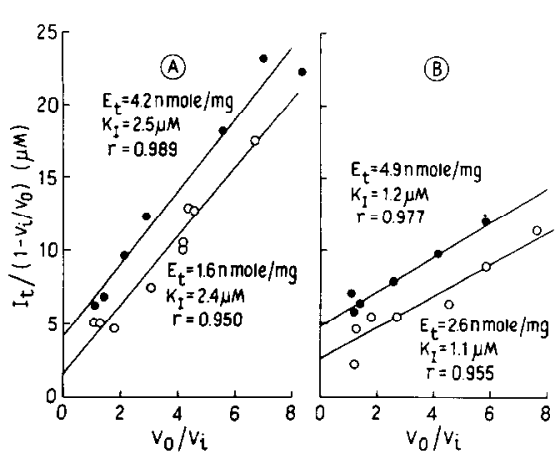

Fig. 3. Oligomycin inhibition of ATP synthesis at $30^{\circ} \mathrm{C}$ plotted according to Eq. [1] on the assumption of enzyme depletion $(20,21)$. The concentration of vesicle protein was $1.0 \mathrm{mg}$ of protein $/ \mathrm{ml}$ of reaction mixture. The vesicles were obtained from normal (O) or hypothyroid (O) rats. The results of two experiments using $20 \mathrm{~mm} \beta$-hydroxybutyrate +1 $\mathrm{mM} \mathrm{NAD}{ }^{+}$as substrate are shown in $\mathrm{A}$; the results of one experiment using $10 \mathrm{~mm}$ succinate as substrate are shown in $\mathrm{B}$. The lines were calculated by a least mean squares method, and values for the oligomycin-sensitive phosphorylation site concentration $\left(E_{\mathrm{t}}\right)$, the inhibitor binding constant $\left(K_{i}\right)$, and the correlation coefficient $(r)$ are indicated. 
ing the $36 \%$ decrease in the number of apparent phosphorylation sites (oligomycin binding sites) with the $45 \%$ decrease in overall phosphorylation supported by $\beta$ hydroxybutyrate (Table I) indicates that a decrease in the number of phosphorylating sites accounts for four-fifths of the decreased phosphorylation at $30^{\circ} \mathrm{C}$. Selective damage of phosphorylation by digitonin extractions of hypothyroid mitochondria seems to be eliminated by previous observations (2) that oligomycin inhibits phosphorylating respiration in intact liver mitochondria during $\beta$-hydroxybutyrate oxidation at $30^{\circ} \mathrm{C}$ three times more in hypothyroids than in normals.

Protein composition. A decrease in the number of phosphorylating sites in vesicles from hypothyroid rats does not appear to be consistent with observations that the $\mathrm{Mg}^{2+}$-activated ATPase, which is thought to reflect a reversal of the last step of ATP synthesis from ADP $+\mathrm{P}_{\mathrm{i}}$ (22), is more active at $30^{\circ} \mathrm{C}$ in the hypothyroid vesicles than in normal vesicles (see above and Fig. 1). To resolve this contradiction, the composition of hypothyroid and normal vesicles was compared in a search for a deficit that would account for the major defects in function. Both proteins and lipids are involved in mitochondrial ATPase activity and ATP synthesis (23). Densitometer profiles of the proteins in vesicles from normal or hypothyroid rats show no major changes in relative polypeptide con-

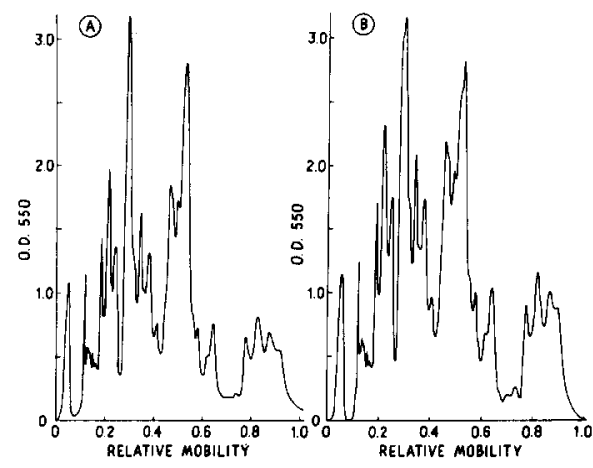

FIG. 4. Densitometer tracings of typical sodium dodecyl sulfate polyacrylamide gel electrophoresis of proteins of the inner membrane vesicles from normal (A) and hypothyroid (B) rats. The relative mobility of the tracking dye was about 1.2. tent (Fig. 4). Similar profiles were obtained from vesicles prepared from thyroxine-injected hypothyroid rats (data not shown).

Phospholipid fatty acid contenls. The rates of many membrane-dependent processes depend on the relative contents of the phospholipid fatty acids (23). Accordingly, the mole fractions of phospholipid fatty acids extracted from the mitochondrial inner membranes were calculated from gasliquid chromatography analyses. The fatty acids are shown in three groups in Table VI, according to the effects of hypothyroidism and of hormone injection among rats fed the same low-iodine diet. The normal rats that were controls for this comparison received, in addition, an iodide supplement in their drinking water to maintain their euthyroid state. The fatty acid distribution in normal rats fed the usual laboratory chow differs only in the contents of two acids that are major components: $18: 1$ is halved and 22:6 is doubled; there are, in addition, smaller but significant changes in long-chain polyunsaturated acids that are minor components. The unsaturation indexes of the fatty acids of these two groups are similar, however, as are the mean carbon lengths and the 20:4/18:2 ratios.

The three groups of fatty acids that can be compared are as follows. Group I fatty acids, 18:0 and 22:6, which are at similar levels in normal and hypothyroid vesicles, are increased after thyroxine injection. This group seems to represent the effects of hyperthyroidism, in that the hormone treatment of euthyroid normal rats has been observed to increase the mitochondrial contents of 18:0 (24) and 22:6 (25) fatty acids. The levels of the fatty acids in Group II, which are significantly differer. in hypothyroid and normal vesicles, are not affected by the injection of thyroxine. Accordingly, their relative contents do not appear to contribute to the hormone-induced correction of inner membrane function. The deficiency of 18:1 fatty acid in hypothyroidism is, however, a factor in the relatively low unsaturation of the membrane fatty acids.

The mole fractions of the Group III acids have been reported in a preliminary com- 
TABLE VI

Fatty Acid Contents of Phospholipids Extracted from the Inner Membrane Vesicles of Mitochondria Obtained From the Livers of Normal, Hypothyroid, and l-Thyroxine-INJected Hypothyroid Rats, in Mole Fractions Percentage ${ }^{a}$

\begin{tabular}{|c|c|c|c|c|c|}
\hline & \multirow[t]{2}{*}{ Fatty acid } & \multicolumn{2}{|c|}{ Normals } & \multirow{2}{*}{$\begin{array}{l}\text { Hypothyroid } \\
\text { low-I diet(9) }\end{array}$} & \multirow{2}{*}{$\begin{array}{l}\text { L-Thyroxine-in- } \\
\text { jected hypothy- } \\
\text { roid low-I diet (8 }\end{array}$} \\
\hline & & Normal diet (8) & Low-I diet (7) & & \\
\hline \multirow[t]{2}{*}{ (I) } & $18: 0$ & $20.8 \pm 0.7$ & $16.3 \pm 0.5$ & $17.4 \pm 0.7$ & $21.4^{b} \pm 0.5$ \\
\hline & $22: 6$ & $7.9^{*} \pm 0.8$ & $3.3 \pm 0.2$ & $3.1 \pm 0.2$ & $5.2^{c} \pm 0.5$ \\
\hline \multirow[t]{4}{*}{ (II) } & $16: 1$ & $0.3 \pm 0.08$ & $0.5^{d} \pm 0.08$ & $1.0 \pm 0.2$ & $0.8 \pm 0.2$ \\
\hline & $18: 1$ & $6.9^{*} \pm 0.4$ & $15.6^{b} \pm 0.3$ & $12.2 \pm 0.4$ & $11.5 \pm 0.4$ \\
\hline & $22: 3$ & $0^{*}$ & $0.3^{h} \pm 0.03$ & $0.1 \pm 0.02$ & $0.2 \pm 0.03$ \\
\hline & $22: 5$ & $0.9^{*} \pm 0.05$ & $0.1^{b} \pm 0.02$ & $0.4 \pm 0.04$ & $0.4 \pm 0.06$ \\
\hline \multirow[t]{9}{*}{ (III) } & $16: 0$ & $14.5 \pm 0.5$ & $13.1^{c} \pm 0.4$ & $15.8 \pm 0.6$ & $13.9^{e} \pm 0.6$ \\
\hline & $18: 2$ & $17.6 \pm 1.2$ & $18.7^{c} \pm 0.5$ & $25.5 \pm 1.9$ & $15.6^{b} \pm 0.7$ \\
\hline & $18: 3$ & 0 & $0^{b}$ & $0.3 \pm 0.03$ & $0^{b}$ \\
\hline & $20: 3$ & $0.1 \pm 0.03$ & $0.1^{b} \pm 0.01$ & $1.0 \pm 0.1$ & $0.3^{b} \pm 0.06$ \\
\hline & $20: 4$ & $28.2 \pm 0.5$ & $29.7^{b} \pm 0.5$ & $22.0 \pm 0.6$ & $28.6^{b} \pm 0.5$ \\
\hline & $22: 4$ & $0.1^{*} \pm 0.02$ & $2.2^{b} \pm 0.2$ & $1.0 \pm 0.1$ & $2.0^{b} \pm 0.1$ \\
\hline & $\begin{array}{l}\text { Unsaturation } \\
\text { index }\end{array}$ & $207.5 \pm 6.3$ & $202.6^{c} \pm 5.4$ & $181.0 \pm 1.4$ & $193.8^{c} \pm 0.9$ \\
\hline & $20: 4 / 18: 2$ & $1.7 \pm 0.1$ & $1.6^{b} \pm 0.1$ & $0.9 \pm 0.1$ & $1.8^{c} \pm 0.3$ \\
\hline & $\begin{array}{r}\text { Mean C } \\
\text { length }\end{array}$ & 17.9 & 18.6 & 18.3 & 18.6 \\
\hline
\end{tabular}

${ }^{a}$ Inner membrane vesicles were prepared as in Table $\mathrm{I}$, and phospholipids were extracted and analyzed for fatty acid contents as described under Materials and Methods. The fatty acid contents in vesicles from two groups of normal rats are compared to show the effects of diet, and the fatty acids of three groups of rats on the low-iodine diet are compared to show the effects of thyroid state. The unsaturation index is $\Sigma$ (mole fraction $\times$ number of unsaturated bonds in each acid). The mean $C$ length is $\Sigma$ (mole fraction $\times$ number of carbon atoms). The number of preparations analyzed is shown in parentheses, and the means \pm SEM are compared by Student's $t$ test. The groupings are discussed in the text.

${ }_{b, c, d, e} P<0.001(b), 0.005(c), 0.025(d)$, or $0.05(e)$ for normals or L-thyroxine-injected hypothyroids versus hypothyroids; all on low-I diet.

* $P<0.001$; normals on normal diet versus normals on low-I diet.

munication (8). These fatty acids are at abnormal levels in hypothyroid vesicles and are brought to normal levels 3 days after the injection of thyroxine; they therefore reflect most directly the effects of hormone deficiency and replacement (8). Although the content of 16:0 fatty acid is significantly increased in hypothyroid vesicles as compared to normal vesicles, the decrease in 16:0 after hormone injection is just barely significant. A docosatrienoate (20:3) and its possible precursors are found in hypothyroid vesicles at higher than normal levels, whereas its possible desaturation products, arachidonate (20:4) and 22:4, are at lower than normal levels. An 18:3 fatty acid appears in the vesicles of hypothyroid rats; one also is reported to appear in the total liver lipids of hypothyroid rats, but it is normally not present in liver (26). The nature of this acid is discussed below. In intact mitochondria from hypothyroid rats, 18:2 has been found to be elevated and 18:0 decreased (27).

A result of these changes in vesicle fatty acid distribution is a $10 \%$ decrease in the unsaturation index in hypothyroidism, which is partly restored after hormone treatment. A further measure of desaturating activity, the ratio of the unsaturated acids 20:4/18:2, is below the normal control value in the untreated hypothyroids and is restored in the treated hypothyroids. The average number of carbons in the fatty acids is not affected by thyroid state. The average dry weight:protein ratios of the phospholipids extracted (not shown in Table VI) were similar in the vesicles ob- 
tained from rats of the various thyroid states, so changes in the fractional contents of fatty acids represent changes in fatty acid:protein ratios.

The unsaturated fatty acids of Group III in Table VI, which respond to hormone deficiency and replacement, would be metabolites of linoleate, 18:2 $\omega 6$, if they were of the $\omega 6$ family. In the absence of definitive analyses of ozonolysis products, a plot. of the logarithm of the retention times versus the carbon numbers of the 18:3, $20: 3$, and $22: 3$ found in hypothyroid vesicles in shown in Fig. 5 to supply inferential evidence for the $\omega$ family of these trienoic acids. The linearity of the plot shows that all three are of the same $\omega$ family, accord-

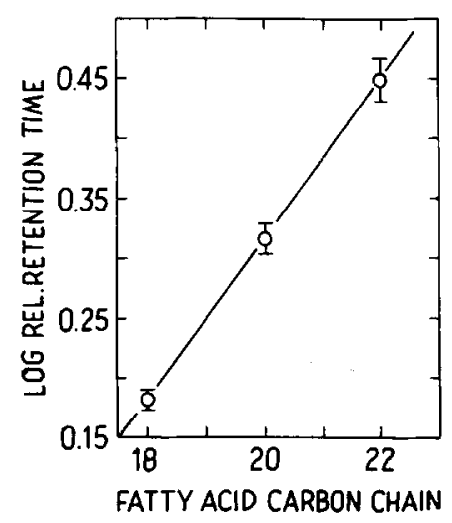

FIG. 5. The relationship between the fatty acids $18: 3,20: 3$, and $22: 3$ that are extracted from inner membrane vesicles of hypothyroid rats. The relative retention times were obtained by gas-liquid chromatography with respect to that of $18: 0$ and are plotted versus the carbon chain lengths according to Ackman (28). The means \pm SEM of four experiments are shown. ing to Ackman (28). The 20:3 and 22:3 fatty acids found in a normal mammalian tissue are both $\omega 6$, as shown by gas-liquid chromatography and ozonolysis (29). Only 20:3 $\omega 6$ is found in liver mitochondria from normal rats fed a diet in which the total lipid is $15 \%$ corn oil, although $20: 3 \omega 9$ also appears when the lipid is $15 \%$ beef fat (30). Our hypothyroid rats were fed a low-iodine diet containing $14 \%$ hydrogenated vegetable oils. Thus, the $20: 3$ is probably $\omega 6$, and the 18:3 $\omega 6$ that appears in hypothyroid vesicles is $\gamma$-linolenate. A $20: 3 \omega 9$ is reported to accumulate in the tissues of rats made deficient in essential fatty acids (31). As there is no report of the biosynthesis of an 18:3 $\omega 9$, it may be inferred that the accumulated $20: 3$ is not the $\omega 9$ isomer. Furthermore, hypothyroidism appears to involve not an absolute deficiency of unsaturated fatty acids, but a redistribution of content that favors the less unsaturated fatty acids.

Mitochondrial and vesicle preparation. In comparing the properties of inner membrane vesicles obtained from hypothyroid and normal rats, the question arises as to whether the method of preparation itself has different effects on the tissues of the two groups of rats. In particular, selective effects of the three digitonin extractions of mitochondria were of concern, as mentioned above. The effects of the digitonin extractions of normal and hypothyroid mitochondria on the recovery of protein and cytochrome $a$ were therefore compared (Table VII). Intact liver mitochondria obtained from hypothyroid rats contain amounts of cytochrome $a$ similar to those

\section{TABLE VII}

Recovery of Total Protein and Cytochrome $a$ in Inner Membrane Vesicles Prepared by Digitonin Extractions of Intact Mitochondria Obtained from Normal and Hypothyroid Rats ${ }^{a}$

\begin{tabular}{lcc}
\hline & Normal & Hypothyroid \\
\hline $\begin{array}{l}\text { Cytochrome } a \text { content of mitochondria (Ref. 32) [pmol } \times(\mathrm{mg} \text { of } \\
\text { protein) }\end{array}$ & $240 \pm 10(6)$ & $230 \pm 10(5)$ \\
Total protein recovered in vesicles $(\%)$ & $23 \pm 2(8)$ & $13^{b} \pm 2(8)$ \\
Cytochrome $a$ recovered in vesicles $(\%)$ & 53 & 31 \\
\hline
\end{tabular}

a Where appropriate, results are given as means \pm SEM. In parentheses is the number of experiments, each of which represents pooled livers from two or three rats. The cytochrome $a$ recovered in the vesicles was calculated from the cytochrome $a$ content of intact mitochondria (32) and of inner membrane vesicles (Table II).

${ }^{b} P<0.005$ 
from normal rats $(32,33)$. When hypothyroid mitochondria are extracted with $0.5 \%$ digitonin, as routinely used here to remove outer membranes (10), $31 \%$ of the cytochrome $a$ and $13 \%$ of the protein are recovered in the vesicles, as compared with $53 \%$ of the cytochrome $a$ and $23 \%$ of the protein when normal mitochondria are extracted. Since no major differences in mitochondrial protein composition are detected (Fig. 4), the altered recovery suggests changes in the protein binding capacities of hypothyroid vesicles.

Extraction of normal or hypothyroid mitochondria with increased amounts of digitonin did not change the relative rates of ATP synthesis of ATPase action, nor did a 2.5-fold variation in the amount of digitonin used per milligram of mitochondrial protein alter the observed patterns of fatty acid composition of vesicles from untreated or hormone-injected hypothyroid rats.

\section{DISCUSSION}

A derangement of oxidative phosphorylation in the intact liver mitochondria of hypothyroid rats is well documented $(2,34)$ and includes a decrease in State 3 respiration at $25-30^{\circ} \mathrm{C}$, which has usually been ascribed to a deficiency of mitochondrial cytochromes that were measured by extraction methods (35). Such a deficiency has in turn been thought to be a part of the generally decreased rate of protein synthesis in the livers of hypothyroid rats (36, 37 ). The present studies on inner membranes indicate that a slowed phosphorylation of $\mathrm{ADP}$ at $30^{\circ} \mathrm{C}$ exists that does not depend on decreased rates of respiration and that the cytochrome contents are at normal levels. A slowed synthesis of liver mitochondrial proteins has not accounted for several changes in hypothyroidism: (a) the increased respiratory control $(2,3)$; (b) the normal rates of reversed electron flow in Site I and the increased rate of energydependent pyridine nucleotide transhydrogenation $(7,38)$; (c) the increased pyridine nucleotide and adenine nucleotide contents and their abnormal compartmentation $(4,7,33,39)$; (d) the altered temperature dependency of the rates of phosphorylation (6-8), ATPase activity (Fig. 1), adenine nucleotide translocation $(4,5)$, and succinoxidase activity (40). Indeed, the rates in category (d) are not slower in preparations from hypothyroid rats as compared with those from normal rats when measurements are made at temperatures above about $30^{\circ} \mathrm{C}$ or below about $20^{\circ} \mathrm{C}$, which is good evidence against a simple depletion of protein enzymes or carriers.

The depressed general synthesis of liver mRNAs and their translation in hypothyroidism might cover a more selective reduction of the synthesis of the mitochondrial proteins that are involved in energy transduction. A specific deficiency of such components in hypothyroidism would also account for the apparent decrease in the number of inner membrane sites that are specific inhibitory receptors for atractyloside (Table V) or oligomycin (Fig. 3). There is evidence against the existence of a protein deficiency that is of a magnitude that would account for these defects in function. Intact mitochondria from hypothyroid rats specifically bind as much ADP as do mitochondria from normal rats and so have a normal complement of atractyloside-sensitive sites $(4,5)$. As measured by an electrophoretic method that detects deficiencies in mitochondrial membrane proteins (41), we observed no major changes in the polypeptide contents of hypothyroid vesicles (Fig. 4) great enough to account for the $47 \%$ decrease in oligomycin-sensitive sites (Fig. 3). On the other hand, a depletion of a principal protein constituent of the inner membrane in hypothyroidism has been reported (42). The question of specific protein deficiencies, especially of a minor component not detected by the usual electrophoretic methods, is still unresolved.

The correction of oxidative phosphorylation in inner membranes after the injection of a hypothyroid rat with hormone entails a 3-day latent period. It also takes 3 days for the hormone to accelerate the general synthesis of proteins in the liver (37), suggesting that the correction may depend on general protein synthesis. Although hormone treatment does not change the mitochondrial cytochrome contents (Table 
II) or the electrophoretic patterns of the inner membrane polypeptides (Fig. 4), more sensitive methods show that thyroid hormones do induce the rapid cytoribosomal synthesis of one or more mitochondrial proteins. Thyroxine injection stimulates the incorporation of labeled amino acids into mitochondrial protein(s) within $3 \mathrm{~h}$ (43).

Mitochondrial protein depletion does not seem to be sufficient or even necessary to account for the abnormalities in hypothyroidism. The redistribution in polyunsaturated fatty acid contents in the inner membrane vesicles is an alternative explanation for which there is indirect evidence. Physiological, nutritional, and genetic factors are known to alter mitochondrial polyenoic fatty acid contents and the Arrhenius profiles of transport and catalytic rates. In yeasts grown in media deficient in essential polyenoic acids and in rats fed similarly deficient diets, the mitochondrial content of these acids is depleted, oxidative phosphorylation is uncoupled or loosely coupled, and both the catalytic and the Arrhenius kinetics of membranelinked enzymes are changed (44-47). In yeasts, the depletion reduces the rate of mitochondrial ATP uptake and its sensitivity to atractyloside and increases the energy of activation for passive permeation by protons (48). Differences in fatty acid composition, oxidative phosphorylation, and rate-temperature responses are also seen in comparisons of mitochondria obtained from homeotherms and poikilotherms (49), cold- and warm-acclimated poikilotherms $(50)$ or mammals $(51,52)$, hibernating and nonhibernating mammals (53), ethanol-fed and sober rats (54), and cultured cell lines grown at different temperatures (55). Particularly convincing for a causal connection between lipid content and mitochondrial function are "lipidswap" experiments on the muscle mitochondria of goldfish acclimated to 5 or $25^{\circ} \mathrm{C}$ environments $(56,57)$. The succinate dehydrogenase proteins obtained from either group have similar electrophoretic mobilities; either protein is activated by the addition of phospholipids, but more by those extracted from the mitochondrial mem- branes of cold-acclimated goldfish than by those extracted from warm-acclimated goldfish. Analogous experiments on oxidative phosphorylation have not been reported, however.

The increased sensitivity of phosphorylation in hypothyroid vesicles toward oligomycin inhibition, which has been interpreted to denote a decrease in the number of effective phosphorylating sites or sites of $\mathrm{X} \sim \mathrm{P}$ activation (Fig. 3), can also denote a change in phospholipid composition. The sensitivity of the yeast mitochondrial ATPase to oligomycin is related to the degree of unsaturation of the fatty acids in the membrane phospholipids (45). We are currently testing the relationship between the membrane contents of hormone-sensitive polyene fatty acids (Group III, Table VI) and phosphorylation sites by their temporal correlations after hormone injection. A recent report (40) indicates that the abnormal Arrhenius profile of liver mitochondrial succinoxidase activity is partly corrected $12 \mathrm{~h}$ after injecting hypothyroid rats with $3 \mu \mathrm{g}$ of thyroxine/g; we have not yet observed changes in phosphorylation as early as this after our dose of $0.5 \mu \mathrm{g} / \mathrm{g}$.

Although the degree of unsaturation of the phospholipids, as expressed by the unsaturation index, is reduced in hypothyroid vesicles (Table VI), the total content of unsaturated fatty acids, expressed as a percentage of total fatty acids as was done by Hulbert et al. (40) in analyses of intact hypothyroid mitochondria, is elevated. In normal vesicles, unsaturated fatty acids comprise $60.5 \%$ of the total and in hypothyroid vesicles $66.6 \%$ (Table VI); these values agree closely with the 61 and 65 to $71 \%$ reported for normal and hypothyroid liver mitochondria (40). We conclude, however, that hypothyroid mitochondrial inner membranes are deficient in unsaturation and that they enter a solidus state at temperatures a few degrees below $37^{\circ} \mathrm{C}$, in contrast to normal membranes that "freeze" below about $23^{\circ} \mathrm{C}(58)$.

The solidity of the hypothyroid membrane between about 20 and $30^{\circ} \mathrm{C}$ appears to account for the alteration in oxidative phosphorylation by changing the environment for the activation reaction for $P_{i}$. 
Energization slows, ATP is hydrolyzed more rapidly, and ADP half-saturates phosphorylation sites more readily. At temperatures above about $30^{\circ} \mathrm{C}$, both hypothyroid and normal membranes are in a fluid state, and, below about $20^{\circ} \mathrm{C}$, both are in a solid state. Differences in oxidative phosphorylation are thereby confined to the intermediate temperatures. The physical state also affects the Hill coefficients of activations or inhibitions of membrane-dependent processes (59), which now could explain observations that the coefficient for the dinitrophenol activation of respiration is positive in liver mitochondria from normal rats, but negative in mitochondria from hypothyroid rats (60).

The latent period of 3 days for the hormonal correction of oxidative phosphorylation is also consistent with the involvement of membrane phospholipids. The normal rapid exchange of the phospholipids of the membranes of liver mitochondria, as well as that of microsomes and nuclei, is retarded in hypothyroidism, and injecting a dose of L-triiodothyronine that is approximately equivalent to that of the L-thyroxine used here stimulates the exchange and synthesis of these phospholipids maximally in 1 to 2 days (61). It remains to be determined if the incorporation of specific polyenoic fatty acids into membrane phospholipids depends nonspecifically on thyroid control of the relative availability of these acids in the cell or on control over the activity of acyltransferases that are specific for certain polyenoic acids.

The pattern of redistribution of the contents of linoleate (18:2) and its metabolites in the mitochondrial inner membranes from hypothyroid rats suggests a decrease in the activity of the microsomal $\Delta 5$-desaturase system $(7,8)$ and the incorporation of fatty acids into the membrane according to their abundance. Whatever the mechanism of the change in polyenoic fatty acid metabolism may be, an altered metabolism should redistribute the fatty acids in the membranes of other liver cell organelles in addition to those of mitochondria. The phospholipids of liver cell nuclei of hypothyroid rats share the abnormalities of the unsaturated fatty acids in liver mitochondria: 18:2 is elevated even more markedly, an 18:3 $\omega 6$ fatty acid appears, $20: 3$ is high, and 20:4 and the longer acids are decreased together with the unsaturation index (62). The involvement of at least two organelle membranes suggests a common defect in unsaturated fatty acid metabolism in the liver of hypothyroid rats.

Although an inferential case can be made for the participation of hormone-responsive polyenoic fatty acid contents in the control of mitochondrial oxidative phosphorylation, it is not clear at present whether one or more of these acids are involved specifically or the general decrease in unsaturation in hypothyroidism is the effective parameter. Correlation of the time courses of the hormone-induced fatty acid changes during the 3 days after hormone injection, with the course of the restoration of normal phosphorylation, should be helpful in deciding between these alternatives. The inner membrane ATPase system of normal rat liver mitochondria is reported to be specifically associated with 18:2 cardiolipins (63), and 18:2 content is under thyroid control (Table VI). There is also evidence that the fatty acids may not be the only controlling lipid component. Sterol depletion seems to account for the insensitivity of the mitochondrial ATPase toward oligomycin in yeast mutants (64), although, as noted above, the fatty acyl unsaturation also controls this sensitivity (45). The selective action that multiple extractions with digitonin exert upon hypothyroid liver mitochondria (Table VII $)^{2}$ suggests the involvement of cholesterol. It is known that cholesterol content modifies Arrhenius profiles (65) and that cholesterol metabolism is abnormal in hypothyroidism (66). A single extraction of hypothyroid mitochondria with a low concentration of digitonin followed by sonication, or the preparation of vesi-

\footnotetext{
${ }^{2}$ Such selective actions might also account for the smaller decrease in the rate of ATP- $P_{i}$ exchange in vesicles prepared from hypothyroid mitochondria as compared to those from normal mitochondria (Table III), which produces the anomaly that hypothyroidism slows the exchange rate in intact mitochondria but not in vesicles.
} 
cles by sonication alone in the presence of dibucaine, produces particles that have similar efficiencies of phosphorylation when obtained from either hypothyroid or normal mitochondria, although the hypothyroids still show an accelerated utilization of oxidative free energy changes by the pyridine nucleotide transhydrogenase (67). Caution in making conclusions is further suggested by our studies on mitochondria from the hearts of hypothyroid rats, in which the time course of the correction of the energy of activation of State 3 respiration after hormone injection does not seem to be completely consistent with the course of correction of any one of the phospholipid fatty acids (68).

The present findings have several important implications for studies on mechanisms of hormone action. (a) Evidence has been advanced that thyroid hormones act directly and reversibly upon liver mitochondrial oxidative phosphorylation (69). Mitochondria from hypothyroid rats are depleted of hormone and are repleted within minutes after hormone injection (70), and liver mitochondria have specific thyroid hormone receptors of even higher affinity than do nuclei (71). We show here that inner membranes are also depleted in total unsaturation in hypothyroidism. Thyroid hormones can not per se literally correct alterations in membrane fatty acyl contents, although perhaps they can mimic the effects of unsaturated fatty acyls. (b) Slowed rate processes reported in hypothyroidism almost always represent measurements at one temperature and are often ascribed to slow synthesis or rapid degradation of the protein enzyme or transporter; such conclusions might be modified if rates were measured at a number of temperatures. (c) Hormonal control over membrane fatty acyl composition is not confined to the thyroid hormones: Insulin controls mitochondrial fatty acid contents $(72,73)$, and one-temperature changes in oxidative phosphorylation are reported in diabetic animals (74-76); aldosterone (77) and vitamin $D_{3}(78)$ control the fatty acid composition of other membranes. Such controls over the rate processes in organelle and plasma membranes may represent one general mechanism for hormone amplification and regulation of metabolism.

\section{REFERENCES}

1. Tata, J. R., Ernster, L., Lindberg, E., Arrhenius, E., Pedersen, S., and Hedman, R. (1963) Biochem. J. 86, 408-428.

2. Носн, F. L. (1968) Arch. Biochem. Biophys. 124, 238-247.

3. Maley, G. F., and Lardy, H. A. (1955) J. Biol. Chem. 215, 377-388.

4. Носн, F. L. (1975) Fed. Proc. 34, 314.

5. Носн, F. L. (1977) Arch. Biochem.Biophys. 178, 535-545.

6. Chen, Y.-D. I. (1975) Fed. Proc. 34, 314.

7. Ноch, F. L., Chen, Y.-D. I., Evans, T. C., Shaw, M. J., AND NeYmark, M. A. (1976) in Proceedings of the Seventh International Thyroid Conference, Boston, 1975 (Robbins, J., and Braverman, L. E., eds.), pp. 347-351, Excerpta Medica, Amsterdam.

8. Chen, Y.-D. I., ANd Hoch, F. L. (1976) Arch. Biochem. Biophys. 172, 741-744.

9. LeBlond, C. P., AND EARTLY, H. (1952) Endocrinology 51, 26-41.

10. Hoppel, L., ANd Cooper, C. (1969) Arch. Biochem. Biophys. 135, 173-183.

11. Gornall, A. G., Bardawill, C. J., and David, M. W. (1949) J. Biol. Chem. 177, 751-766.

12. Conover, T. E., Prairie, R. J., and Racker, E. (1963) J. Biol. Chem. 238, 2831-2837.

13. Pullman, E. M. (1969) in Methods in Enzymology (Estabrook, R. W., and Pullman, M. E., eds.), Vol. 10, pp. 57-60, Academic Press, New York.

14. Martin, J. B., AND Doty, D. M. (1949) Anal. Chem. 21, 965-967.

15. Chance, B. (1957) in Methods in Enzymology (Colowick, S. P., and Kaplan, N. O., eds.), Vol. 4, pp. 273-329, Academic Press, New York.

16. Weber, K., and Osborn, M. (1969) J. Biol. Chem. 244, 4406-4412.

17. Folch, J., Lees, M., and Sloane-Stanley, G. H. (1957) J. Biol. Chem. 226, 497-509.

18. Morin, R. J., Bernick, S., Mead, J., and AnFIN-Slater, R. B. (1962) J. Lipid Res. 3, 432438.

19. Dixon, M., ANd Webr, E. C. (1958) in The Enzymes (Boyer, P., ed.), p. 782, Academic Press, New York.

20. Henderson, P. J. F. (1972) Biochem. J. 127, 321333.

21. Goldstein, A. (1944) J. Gen. Physiol. 27, 529580.

22. RACKeR, E. (1970) in Membranes of Mitochondria and Chloroplasts (Racker, E., ed.), pp. 127-171, Van Nostrand Reinhold, New York. 
23. Fox, C. F. (1975) MTP Int. Rev. Sci., Biochemistry (Series 1). 2, 279-306.

24. Patron, J. F., and Platner, W. S. (1971) Proc. Soc. Exp. Biol. Med. 137, 196-201.

25. Peifer, J. J. (1968) J. Lipid Res. 9, 193-199.

26. Guarnieri, M., and Johnson, R. M. (1970) Advan. Lipid Res. 8, 115-173.

27. Patton, J. F., and Platner, W. S. (1970) Amer. J. Physiol. 218, 1417-1422.

28. Ackman, R. G. (1962) Nature (London) 194, 970971.

29. Holman, R. T. (1964) Fed. Proc. 23, 1062-1067.

30. Century, B., and Horwitt, M. K. (1963) $J$. Nutr. 80, 145-150.

31. Peluffo, R. O., Brenner, R. R., And Mercuri, O. (1963) J. Nutr. 81, 110-116.

32. Neymark, M. A. (1975) Thesis, University of Michigan, Department of Biological Chemistry.

33. Kadenbach, B. (1966) Biochem. Z. 344, 49-75.

34. Носн, F. L. (1962) Physiol. Rev. 42, 605-673.

35. Drabin , D. G. (1950) J. Biol. Chem. 182, 335349.

36. Dutort, C. (1951) in Phosphorus Metabolism (McElroy, W. D., and Glass, G., eds.), Vol. 1, pp. 597-617, Johns Hopkins Press, Baltimore.

37. TATA, J. R. (1957) Biochem. J. 104, 1-16.

38. Evans, T. C., ANd Hoch, F. L. (1976) Biochem. Biophys. Res. Commun. 69, 635-640.

39. Носн, F. L. (1976) J. Bioenerg. Biomem . 8, 223238.

40. Hulbert, A. J., Augee, M. L., and Raison, J. K. (1976) Biochim. Biophys. Acta 455, 597601.

41. Ebner, E., Mason, T. L., ANd Schatz, G. (1973) J. Biol. Chem. 248, 5369-5378.

42. Baudry, M., Clot, J. P., ANd Michel, R. (1975) Biochimie 57, 77-83.

43. Herd, P., Kaplay, S. S., and Sanad, D. R. (1974) Endocrinology 94, 464-474.

44. Klein, P. D., and Johnson, R. M. (1954) J. Biol. Chem. 211, 103-110.

45. Haslam, J. M., Сobon, G. S., and Linnane, A. W. (1974) Biochem. Soc. Trans. 2, 207-209.

46. Stancliff, R. C., Williams, M. A., Utsumi, K., AND Packer, L. (1969) Arch. Biochem. Biophys. 131, 629-642.

47. Janki, R. M., Aithal, H. N., McMurray, W. C., and Tustanoff, E. R. (1974) Biochem. Biophys. Res. Commun. 56, 1078-1085.

48. Haslam, J. M., and Fellows, N. F. (1975) Biochem. Soc. Trans. 3, 772-775.

49. Richardson, T., ANd Tappel, A. L. (1962) $J$. Cell Biol. 13, 43-53.

50. Hazel, J. R., ANd Prosser, C. L. (1974) Physiol. Rev. 54, 620-677.

51. Chaffee, R. R. J., Hoch, F. L., and Lyman, C. (1961) Amer. J. Physiol. 201, 29-32.

52. Roberts, J. C., and Chaffee, R. R. J. (1973) Comp. Biochem. Physiol. 44, 137-144.
53. Raison, J. K., and Lyons, J. M. (1971) Proc. Nat. Acad. Sci. USA 68, 2092-2094.

54. Miceli, J. N., ANd FerRell, W. J. (1973) Lipids 8, 722-727.

55. Ferguson, K. A., Glaser, M., Bayer, W. H., AND Vagelos, P. R. (1975) Biochemistry 14, 146-151.

56. Hazel, J. R. (1972) Comp. Biochem. Physiol. 43B, 837-861.

57. Hazel, J. R. (1972) Comp. Biochem. Physiol. 43B, 863-882.

58. Lee, M. P., ANd Gear, A. R. J. (1974) J. Biol. Chem. 240, 7541-7549.

59. Farias, R. N., Bloj, B., Morero, R. D., SiNeriz, F., ANd Trucco, R. E. (1975) Biochim. Biophys. Acta 415, 231-251.

60. Носн, F. L. (1968) Arch. Biochem. Biophys. 124, 248-257.

61. TATA, J. R. (1967) Nature (London) 213, 566-569.

62. Shaw, M. J., and Hoch, F. L. (1976) Life Sci. 19, 1359-1364.

63. Lopez-Moratalla, N., Segovia, J. L., AND Santiago, E. (1973) Revisla Española de Fisiologia 29, 329-334.

64. Swanluung, P., and Swanluung, H. (1973) in Mechanisms in Bioenergetics (Azzone, G. F. Ernster, L., Papa, S., Quagliariello, E., and Siliprandi, N., eds.), pp. 599-605, Academic Press, New York.

65. Hinz, H. J., and Sturtevant, J. M. (1972) J. Biol. Chem. 247, 3697-3700.

66. Gries, F. A., Matschinsky, F., and Wieland, O. (1963) Symp. Deut. Ges. Endocrinol. 9, 149152.

67. Evans, T. C. (1976) Thesis, University of Michigan, Department of Biological Chemistry.

68. Shaw, M. J., and Hoch, F. L. (1977) J. Mol. Cell. Cardiol. 9, in press.

69. Hoch, F. L., ANd Motta, M. V. (1968) Proc. Nat. Acad. Sci. USA 59, 118-122.

70. Dillon, R. S., AND Hoch, F. L. (1967) Biochem. Med. 1, 219-229.

71. Sterling, K, and Milch, P. O. (1975) Proc. Nat. Acad. Sci. USA 72, 3225-3229.

72. Lerner, E., Shug, A. L., Elson, C., ANd Shrago, E. (1972) J. Biol. Chem. 247, 15131519.

73. Mercuri, O., Peluffo, R. O., and Brenner, R. R. (1967) Lipids 2, 284-285.

74. Matsubara, T., and Tochino, Y. (1970) J. Biochem. 68, 731-736.

75. RYER, R., III, AND MURLIN, J. R. (1951) Endocrinology 48, 75-87.

76. Salmon, D. M. W., and Helms, D. A. (1975) Biochem. Soc. Trans. 3, 510-512.

77. Goodman, D. B. P., Wong, M., and Rasmussen, H. (1975) Biochemistry 14, 2803-2809.

78. Goodman, D. B. P., Haussler, M. R., and Rasmussen, H. (1972) Biochem. Biophys. Res. Commun. 46, 80-86. 